Case Study

http://dx.doi.org/10.17784/mtprehabjournal.2014.12.179

\title{
Effect of running exercise with and without the use of equipment Kangoo Jumps, in postural control: a case study.
}

\author{
Efeito do exercício de corrida com e sem a utilização do equipamento Kangoo Jumps, no con- \\ trole postural: estudo de caso.
}

\begin{abstract}
Rodrigo Franco de Oliveira(1), Priscila Daniele de Oliveira(2), Stheace Kelly Fernandes Szezerbaty(2), Laís Campos de Oliveira(3), Juliana Serpeloni de Almeida(2), André Wilson de Oliveira Gil(2), Vitor Hugo Antunes Assis $^{(4)}$ Raphael Gonçalves de Oliveira(5)
\end{abstract}

Centro de Ciências Biológicas e da Saúde, Universidade Norte do Paraná (UNOPAR), Londrina (PR), Brazil.

\begin{abstract}
Introduction: There is increasing interest from the general population, the search for the most suitable and safe exercise programs. Some equipment, such as Kangoo Jumps (KJ), allows performing exercises with less impact on the joints, and probably infer on postural control. Objective: To investigate the effect of exercise submaximal exercise running with and without the use of equipment KJ on postural control variables. Method: Participated in the study with an individual 20 years old, male, equivalent to $86 \mathrm{~kg}$ of body weight. The test was to evaluate the postural balance using a force platform with bipedal before and after conventional and adapted from Cooper (using the $\mathrm{KJ}$ ) test support. The equilibrium parameters were recorded: (A- COP in $\mathrm{cm}^{2}$ ) of displacement of the center of pressure; average swing speed of the COP (MVeloc in $\mathrm{cm} / \mathrm{s})$ in the anteroposterior planes $(A / P)$ and medial-lateral $(M / L)$. Results: The results showed that after using the equipment KJ, A-COP (-39.70\%) MVeloc the A/P (-20.66\%) and M/L $(-20.48 \%)$ were best compared with the race without using $\mathrm{KJ}$ test. Conclusion: It is concluded that after running exercise on submaximal exercise with the use of equipment $\mathrm{KJ}$ had become favorable outcome for postural balance. One such reason would be because of its system of absorption and dissipation of impact, which allows a better activation of the proprioceptive system through increasing the speed of afferent estimate. The intervention of this study shows that the use of the $\mathrm{KJ}$ has significant equipment to maintain postural stability near control values benefits. However, further studies are needed, due to lack of evidence of the parameters of this equipment and the small number in our sample.
\end{abstract}

Keywords: exercise; postural balance; running.

\section{Resumo}

Introdução: É crescente o interesse por parte da população em geral, pela busca de programas de exercícios físicos mais adequados e seguros. Alguns equipamentos, como o Kangoo Jumps (KJ), possibilitam a realização de exercícios com menor impacto sobre as articulações, além de provavelmente inferir sobre o controle postural. Objetivo: Verificar o efeito do exercício de esforço submáximo de corrida, com e sem a utilização do equipamento $\mathrm{KJ}$, sobre variáveis do controle postural. Método: Participou do estudo um indivíduo com 20 anos de idade, sexo masculino, peso corporal equivalente a $86 \mathrm{~kg}$. O teste consistiu em avaliar o Equilíbrio Postural utilizando uma plataforma de força com apoio bipodal, pré e pós teste de Cooper convencional e adaptado (com o uso do KJ). Os parâmetros de equilíbrio registrados foram: área de deslocamento do centro de pressão $\left(A-C O P\right.$ em $\mathrm{cm}^{2}$ ); velocidade média de oscilação do COP (MVeloc em $\mathrm{cm} / \mathrm{s}$ ) nos planos ântero-posterior $(A / P)$ e médio-lateral (M/L). Resultados: Os resultados demonstraram, que após o uso do equipamento $\mathrm{KJ}$, a $\mathrm{A}-\mathrm{COP}$ $(-39,70 \%)$, a MVeloc A/P $(-20,66 \%)$ e M/L $(-20,48 \%)$ foram melhores, quando comparadas com o teste de corrida sem o uso do KJ. Conclusão: Conclui-se que após o exercício de corrida em esforço submáximo, com a utilização do equipamento $\mathrm{KJ}$ teve-se resultado favorável para o equilíbrio postural. Um desses motivos seria por causa do seu sistema de absorção e dissipação de impacto, que possibilita uma melhor ativação do sistema proprioceptivo, através do aumento da velocidade do estimo aferente. A intervenção deste estudo mostra que a utilização do equipamento KJ tem benefícios significativos para manter a estabilidade postural em valores próximos ao controle. Porém, novos estudos são necessários, devido à escassez de comprovações dos parâmetros deste equipamento e o número pequeno de nossa amostra.

Palavras-chave: exercício; equilíbrio postural; corrida.

Received: 25 February 2014. Accepted: 23 May 2014. Published: 30 May 2014.

1. Professor of associated Master PhD program of UEL/UNOPAR in Ciências da Reabilitação and professional Master in Exercício Físico na Promoção de Saúde. Universidade Norte do Paraná (UNOPAR), Londrina (PR), Brazil.

2. Professor of associated Master program UEL/UNOPAR in Ciências da Reabilitação, Universidade Norte do Paraná (UNOPAR), Londrina (PR), Brazil.

3. Professor of prefessional Master in Exercício Físico na Promoção de Saúde, Universidade Norte do Paraná (UNOPAR), Londrina (PR), Brazil.

4. Professor of Physical Therapy School, Universidade Norte do Paraná (UNOPAR), Londrina (PR), Brazil.

5. Professor of Centro de Ciências da Saúde, Universidade Estadual do Norte do Paraná (UENP), Jacarezinho (PR), Brazil. 


\section{INTRODUCTION}

Currently, the growing technological development, increasing the number of people who become sedentary, with few recreational opportunities for physical activity. (1) Sedentary lifestyle is not only a personal risk of disease, and also an economic cost to the individual, family and society. (2) Physical activity is a complex behavior influenced by several factors, including: age, socioeconomic status, education and gender. ${ }^{(3)}$

The growing interest in the practice of physical activity causes people to seek more suitable for certain purposes exercise programs, and that the same, enable the security practitioner. ${ }^{(4)}$ An example is Kangoo Jumps (KJ) footwear. ${ }^{(5)}$

After 13 years of research, an engineer named Denis Naville, revolutionized the concept of footwear that provides a low impact on the joints and other tissues, thus creating the $\mathrm{KJ}$. This footwear has been added comfort, design, quality and performance. $\mathrm{KJ}$ is currently marketed internationally and is present in 24 countries, including Brazil. The equipment has a variety of benefits. Among them we can mention the reduced impact up to $87 \%$, correction and postural realignment, improved coordination and postural balance. ${ }^{(5)}$

The conservation of upright body posture is an important and complex task for the human body, in regards to alignment and body control. Remain standing oscillations requires the body to maintain balance. This maintenance activity is the product of the vestibular system, somatosensory system and visual system. ${ }^{(6)}$

Therefore, the following question could be asked: how much exercise submaximal exercise racing influence postural control using the $\mathrm{KJ}$ ? The hypothesis is that the equipment is capable of enabling the practitioner a better postural balance compared to no use. Thus, the aim of this study was to investigate the effect of exercise submaximal exercise running with and without the use of equipment $\mathrm{KJ}$, on postural control.

\section{METHODS}

This research was characterized as a case study, with an individual 20 years of age, male gender, body weight equivalent to $86 \mathrm{~kg}$, a resident of the city of Londrina, Paraná, Brazil. The same was practicing and racing fan equipment Kangoo Jumps (KJ). The whole process of research conformed to the ethical principles with signing the Consent and approval of the research project in the Local Ethics Committee (196/96 National Health Council).

\section{Assessment}

The postural balance test used a force platform (400 BIOMEC, EMG System of Brazil Ltda), with bipedal support. The protocol was standardized: barefoot, arms loose and relaxed at your sides and your feet horizontally positioned cephalic segment to the plane of the ground, eyes open and directed to a fixed target (black cross $=14.5 \mathrm{~cm}$ high $\times 14.5 \mathrm{~cm}$ wide $\times 4 \mathrm{~cm}$ thick) positioned on the wall and at the same time the eyes, in front distance of $2.5 \mathrm{~m}$. Three trials of 45 seconds with 10 seconds rest between them were performed.

The parameters of balance from the force platform; (A-COP in $\mathrm{cm}^{2}$ ) of displacement of the center of pressure and the speed of oscillation of the COP (MVeloc in $\mathrm{cm} / \mathrm{s}$ ) in both planes, anterior-posterior (A/P) and medial-lateral $(M / L)$ were quantified to assess postural control. For acquisition and processing parameters balance himself Bioanalysis BIOMEC400 software platform, which is compiled computer analysis routines MATLAB (The Mathworks, Natick, MA) was used.

The analysis of Postural Balance, the 12-minute test proposed by Cooper (aiming to develop an activity of the evaluated individual submaximal effort) was performed. The Cooper test is to predict the maximum oxygen uptake (VO2 max). ${ }^{(7)}$ At the end of the test a new analysis of Postural Balance (post-test) was performed. After 48 hours, the same procedure was performed (evaluation of pre and post balance running test), however, the Cooper test was adapted, using the KJ equipment (Health Emporium, Brazil).

\section{Statistical Analysis}

Since this was a case study, data were analyzed using descriptive statistics (mean and standard deviation). To balance the parameters recorded by the force platform: A-COP and MVeloc (A/P and M/L) in three attempts, the average was calculated.

\section{RESULTS}

Table 1 presents the results obtained by the parameters analyzed. It was established that the use of the equipment during $\mathrm{KJ}$ Cooper test, showed better postur-

Table 1. Values (mean \pm standard deviation) pre and post-test sith and without Kangoo Jumps (KJ) equipment.

\begin{tabular}{lccc}
\hline Variables & Pre-test & Post without KJ & Post with KJ \\
\hline A-COP $\left(\mathrm{cm}^{2}\right)$ & $1.02 \pm 0.30$ & $1.99 \pm 0.65$ & $1.20 \pm 0.43$ \\
MVeloc A/P (cm/s) & $0.65 \pm 0.01$ & $1.21 \pm 0.10$ & $0.96 \pm 0.05$ \\
MVeloc M/L (cm/s) & $0.54 \pm 0.07$ & $0.83 \pm 0.07$ & $0.66 \pm 0.07$
\end{tabular}

Subtitle: A-COP - area of displacement of the center of pressure $\left(\mathrm{cm}^{2}\right)$; MVeloc - oscillarion mean speed of COP (cm/s) on planes A/P (antero-posterior) and $\mathrm{M} / \mathrm{L}$ (mediolateral). 
al control for all variables analyzed at submaximal posttest, when compared with no use of the equipment.

Comparing the two moments after the Cooper test, you can check a percentage difference of $-39.70 \%$ for A-COP (cm2), $-20.66 \%$ for MVeloc A/P (cm/s) and $-20.48 \%$ for MVeloc $M / L(\mathrm{~cm} / \mathrm{s})$, in favor of using the KJ (Graph 1) equipment.

\section{DISCUSSION}

The globalization, associated with accelerated development and technological innovations; every day new devices come to market, using high technologies. The sports field, the intent is usually related to improved performance, increased energy expenditure and improvement of postural control in different equilibrium conditions; based on these precepts $\mathrm{KJ}$ provides several benefits of moving through the mechanism called Rebound. ${ }^{(5)}$

According to Brito, ${ }^{(8)}$ the operation of the impactabsorbing system is based on the laws of physics and especially influenced the action of the gravitational force in our body, which defines that we are constantly subjected to three forces: gravity, the acceleration and deceleration. In common situation, when done walking or running, these forces are represented graphically by vectors in the following way: gravity-vertical-horizontal acceleration and deceleration-horizontal.

When jumps are performed in body mass is moving (accelerating and decelerating) in the same direction as the force of gravity (vertically). In the ascent phase a significant strength of the muscles so that the body is taken out of the soil, winning the attraction of the gravitational force is required. At the stage of the descent, the gravitational force provides a downward acceleration, which increases the shock (impact with the ground). For the body to take advantage of this phase of descent and get benefits of various orders, one can make use of intelligent mechanisms which are able to absorb this impact and transform it into positive energy, or facilitator of the movement. Thus, this mechanism is called Rebound. ${ }^{(9)}$

Rebound in $\mathrm{KJ}$ is optimized by the absorption and dissipation of impact (IPS) system, which provides an increased activation of the proprioceptive system through increasing the speed of afferent stimulation. The IPS is located at the bottom of equipment structure, and is formed by a set of elastic members constituted by parts arranged in the horizontal direction, ie perpendicular to the path of movement. The soil is pushed vertically and the energy is dissipated in the fall, horizontally, through the elastic system that returns energy, increasing the ability to scroll forward and, to a lesser extent, to the top (floating). (8)

Thus, KJ provides to its fans, a great range of benefits, including the postural control through the sys-

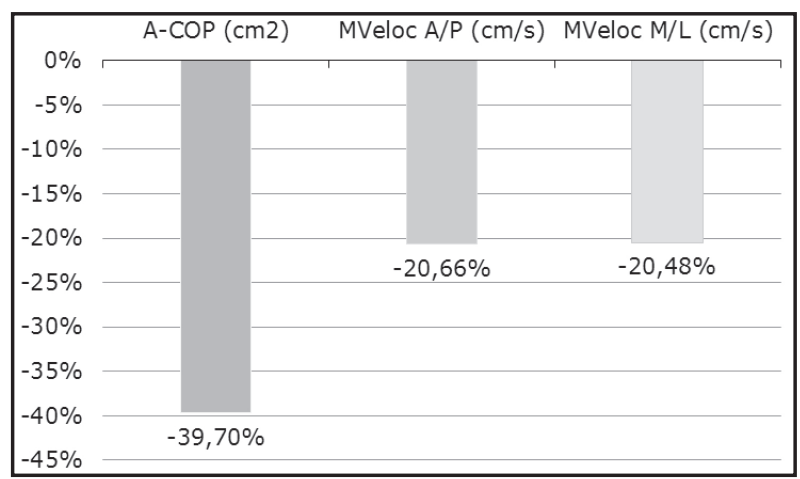

Graph 1. Comparison (percentage difference) post-Cooper test with and without the use of Kangoo Jumps equipment.

tems that surround this mechanism.(10) Different muscle compensations and strategies of postural adjustments, through muscle activation should be made to preserve joint stability and thus reduce the loss of balance. This has been highlighted by recent research, which uses the application of landing tests to evaluate the settling time after a certain jump. The dynamic postural control task during a jump, for example, is reduced in subjects with chronic ankle instability and these individuals use different strategies to restore balance regarding the normal.(11)

Postural control is associated with neuromuscular and biomechanical mechanisms for achieving a proper balance in movement during dynamic and/or static situation. ${ }^{(12)}$ Biomechanically, the balance can be defined as the ability to maintain the body center of mass, relative to the projection of its center of gravity over the base area to sustain the body. During static posture or during movement, the human body uses postural strategies for maintaining balance (neuromuscular postural adjustments, such as proprioceptive information and the use of force in support: pressure of the feet) to preserve the center of mass of the body within the supporting base.

Thus, according to the results obtained in this study, the ellipse COP area can expressed as average values of the A-COP, represent the following values: control test (benchmark) $1.02 \mathrm{~cm}^{2}$, test carried out with the use of shoes during the test Cooper $1.99 \mathrm{~cm}^{2}$ and, test performed with use of the $\mathrm{KJ}$ equipment during Cooper $1.20 \mathrm{~cm}^{2}$ test; from the data we can infer that the use of $\mathrm{KJ}$ equipment, presents less instability compared to training without this equipment, based on average values of the A-COP, supposed by the benefits generated by the rebound effect during training, associated with reduced impacts and consequent decrease in muscle fatigue, contributing to the maintenance of dynamic joint stability.

These initial findings corroborate with the study of Gazzola et al. ${ }^{(13)}$ which demonstrate the instability or impaired balance, occurs through a combination of varying losses in the components of the posture control mechanism. According to Maciel and Guerra ${ }^{(14)}$ balance control 
requires maintaining the center of gravity over the base of support during static and dynamic situation, a process that occurs effectively by the action of visual, vestibular and somatosensory systems.

Corroborating with our findings, the studies of Leporace, Metsavaht and Sposito(15) determined that the improved dynamic stiffness is another important aspect; indicating that muscle receptors increase their sensitivity with increasing dynamic stiffness and exercises involving eccentric training as downhill steps and landings after jumps, and more efficient to increase the preparatory dynamic stiffness and reactive.

In the same study, the authors describe that proprioceptive stimuli, such as those from afferent information from "proprioceptors", located on the "proprioceptive field", directly contribute to the regulation of the global posture (postural balance), segmental posture (joint stability), as well and for various aware peripheral sensations called "muscular sensations."

Leporace, Metsavaht and Sposito(15) explain that proprioception is defined as the set of information originating from the joints, muscles, tendons and other tissues designed for central nervous system (CNS), processing, influencing reflex responses and motor control volunteer. Proprioception contributes to the control of posture, joint stability and diverse conscious sensations. Thus, part of the somato-sensory system. This includes all mechanical information originated by mechanoreceptors, painful, caused by thermal nocireceptors, originated by thermoreceptors. Proprioceptive informa- tion is coming from the muscle and tendon receptors, called muscle spindle and Golgi tendon organ and receptors located in the ligaments, joint capsules, menisci and skin tissues.

The proprioceptive information generated by mechanoreceptors in this process is more effective since they are carried by afferent pathways to the central nervous system (CNS) where they are processed and scheduled new forms of muscle activation to stabilize the joints. Unconscious activation of the dynamic stabilizers occurs in preparation for a response to joint movement is called neuromuscular control. ${ }^{(15)}$

As a limitation of this study may be mentioned the use of a single volunteer (case study), which makes generalizations from the data found. Thus, it is suggested for further studies that investigated the variable here, is tested with the highest number of volunteers and in populations with different characteristics.

\section{CONCLUSION}

It is concluded that after running exercise on submaximal exercise with the use of Kangoo Jumps equipment, had become a best result for balancing variable, compared with the same test without the use of this equipment. One such reason appears to be associated with the absorption and dissipation of impact system, which allows a better activation of the proprioceptive system through increasing the speed of afferent estimate. However, further studies are needed, due to lack of evidence of the parameters of this equipment.

\section{REFERENCES}

1. Pintanga FJG, Lessa I. Prevalência e fatores associados ao sedentarismo no lazer em adultos. Cad Saúde Pública. $2005 ; 21(3): 870-7$

2. Matsudo SM, Matsudo VR, Araujo T. Nível de atividade física da população do Estado de São Paulo: análise de acordo com gênero, idade, nível socioeconômico, distribuição geográfica e de conhecimento. Rev Bras Ciên Mov. 2002;10(4):41-50.

3. Thomaz PMD, COSTA THM, SILVA EF, HALLAL PC. Factors associated with physical activity in adults in Brasília, Central-West Brazil. Rev. Saúde Publica. 2010;44(5):894-900.

4. Silva RS, Silva I, Silva RA, Souza L, Tomasi E. Atividade física e Qualidade de vida. Ciênc Saúde Coletiva. 2010;15(1):115-20.

5. Brito ACM. Treinamento Internacional Kangoo Jumps Fitness Instructor. $1^{\circ}$ Ed. Santos: Editora; 2010.

6. Shumway-Cook A, Wollacott H. Motor Control-Theory and Practical Applications. Baltimore, Md: Lippincott Williams \& Wilkins; 2000.

7. Queiroga MR. Testes e medidas para avaliação da Aptidão física relacionada à saúde em adultos. Rio de Janeiro: Editora Guanabara; 2005.

8. Brito ACM. Treinamento Kangoo Jumps Fitness Instructor. $2^{\circ}$ Ed. Londrina: Editora; 2011.

9. Carter AE. Rebound Exercise: The ultimate exercise for the new millennium. Bloomington: AuthorHouse; 2006.

10. Newton RU, Humphries BJ, Ward IB. Reducing Ground impact Forces During Jogging. Center for Exercise Science and sport Management Southern Cross University. Lismore, 2007.

11. Eechaute $\mathrm{C}$, Vaes $\mathrm{P}$, Duquet $\mathrm{W}$. The dynamic postural control is impaired in patients with chronic ankle instability: reliability and validity of the multiple hop test. Clin J Sport Med. 2009;19(2):107-14. 
12. Winter, D.A. Human balance and posture control during standing and walking. Gait Posture. 1995;3(4):193-214.

13. Gazzola JM, Perracini MR, Ganança MM, Ganança FF. Functional balance associated factors in the elderly with chronic vestibular disorder. Rev Bras Otorrinolaringol. 2006;72(5):683-90.

14. Maciel ACC, Guerra RO. Prevalência e fatores associados ao déficit de equilíbrio em idosos. Rev Bras Ciênc Mov. 2005;13(1):37-44.

15. Leporace G, Metsavaht L, Sposito MMM. Importância do treinamento da propriocepção e do controle motor na reabilitação após lesão músculo-esqueleticas. Acta fisiátrica; 2009;16(3):126-31. 